\title{
Study of main grapevine viruses transmission in breeding programs
}

\author{
Marica Gasparro, Angelo Raffaele Caputo, Lucia Rosaria Forleo, Rocco Perniola, Vittorio Alba, Rosa Anna Milella, \\ and Donato Antonacci
}

Council for Agricultural Research and Economics (CREA) - Unità di ricerca per l'uva da tavola e la vitivinicoltura in ambiente mediterraneo, via Casamassima 148, 70010 Turi (BA), Italy

\begin{abstract}
A number of studies have established that vertical transmission of viruses is an important phenomenon affecting a wide range of viruses, especially as a result of breeding programs. Nevertheless, the presence of virus in a seed, does not always lead to seedling infection. In grapevine, seed transmission has been reported for many nepoviruses, but little is known about the other virus associated diseases such as Leafroll, Rugose wood complex and Fleck diseases, that are considered by Italian legislation on certification of grapevine propagation material, together with infectious degeneration. Thus, the aim of this study is monitoring the virological condition of seedlings obtained by crosses between infected parentals, analyzing the sanitary status of seedlings after the transfer in experimental fields. In this study, 50 progeny plants from three different traditionally crossbreed seeded and seedless table grape cultivars were investigated for the detection of nine grapevine viruses. It was observed that the viral state of parentals was quite compromised, while viruses were not detected in any of the 150 progeny plants, demonstrating that the main grapevine viruses are at low risk for seed transmission. These results could make it possible to reduce the precautions to obtain propagation material free from infectious diseases and also suggest to consider reproduction as a new procedure of sanitation in breeding programs.
\end{abstract}

\section{Introduction}

Seed transmission plays an important role in the dissemination of some viruses, especially as a result of breeding programs [1]. In fact, seed and, to a lesser extent, pollen are the natural pathway through which some plant viruses are transmitted to the progeny of hosts (vertical transmission) and spread to the environment [2]. Moreover, seed transmission of viruses is of great epidemiological importance, because it enables them to escape unfavorable conditions and survive from season to season [3].

About $20 \%$ of plant viruses are seed transmitted [4,5] but little is known about the mechanisms involved in vertical transmission. Seed transmission of a virus can occurs by contamination of outer surface of seed or of part of maternal seed, this non-embryonal transmission is typical of viruses resistant to degradation, which are very infectious and easily transmissible by contact. Conversely, embryonal transmission is achieved either by direct invasion of the embryo via the ovule, during its development after fertilization, or by indirect invasion of the embryo, mediated by infected gametes, by invasion of reproduction tissues and organs before embryogenesis [6]. The direct and indirect embryonal transmission affects viruses that extensively invade parenchymal tissues and are transmitted by mechanical inoculation. However, little is known about how viruses can move from sporophytic to gametophytic tissues and back again into sporophytic tissues [1].

The presence of virus in a seed, even in the embryo, does not always lead to seedling infection: in many cases, in fact, during metabolic processes associated with germination, the virus is degraded and loses its infectivity. Seed transmission depends on the ability of a virus to invade and replicate in the host reproductive tissues and to overcome without damage the physiological modifications associated to seed maturation. This property distinguishes a seed borne virus that is carried by the seed but does not infect the seedling, from a seed-transmitted virus that does infect the seedling produced from the seed [7].

In general, seed transmission occurs more frequently in herbaceous crops rather than in the woody plants, but seed transmission in herbaceous crops is not a risk to genetic breeding, because it is not difficult to find healthy parental material as the selection is made on a high number of individuals. In the case of fruit trees, instead, the presence of viruses in many variety collections used as source of breeding material (pollen or seeds) necessitates the development of specific protocols, that exclude or control the presence of agents that might compromise the sanitary status and therefore the spread in the propagation material. Furthermore, it is known that "healthy" plants (in which viruses have not been detected) offer better performance in terms of vegetative growth, lower sensitivity to other diseases, increased productivity and fruit quality [2].

In particular, seed transmission in grapevine has been reported for many nepoviruses as Grapevine Bulgarian latent virus (GBLV) [8], Peach rosette mosaic virus (PRMV) [9], Blueberry leaf mottle virus (BLMoV) [10], Tomato ringspot nepovirus (TomRSV) [10] and specially for Grapevine fanleaf virus (GFLV). GFLV is the most well-characterized nepovirus: it is the most widespread 
and important cause of infectious degeneration disease worldwide. GFLV is rarely if ever transmitted to the embryo of Vitis vinifera and abundant in the endosperm of seed from infected vines. However, it is transmitted through seed to seedling in Chenopodium amaranticolor [11], C. quinoa and soybean and it occurs in pollen of grapevine and herbaceous hosts [12]. There are conflicting reports on seed transmission in grapevines: natural GFLV infections have been detected in weeds in Hungary and Iran [13], moreover the transmission of GFLV through grapevine seeds has been reported by Lazar et al. [14], but it has negligible epidemiological significance.

However, Grapevine rupestris stem pitting associated virus (GRSPaV) might be a potential danger as it has been reported to be present in pollen [15] and seeds [16], but it has not been proved to be seed-transmitted. GRSPaV is restricted to grapevines, is not mechanically transmissible, and is not known to spread naturally. The virus is found in pollen grains and seeds, but these sources do not give rise to infected seedlings [17]. RT-PCR assays on GRSPaV transmission through pollen and seeds detected the virus in pollen collected from infected 110 Richter rootstocks, but showed that it seems to be present on the outer surface rather than inside pollen grains $[18,19]$.

Finally, little is known about the other viral diseases that affect grapevine as Leafroll, Rugose wood complex [20-22] and Fleck diseases (GFkV), that are considered by the Italian legislation on certification of grapevine propagation material, together with infectious degeneration (Decree 2005/43/CE of 23 June 2005). Although there is circumstantial evidence that GFkV spreads naturally in the field, no vector has been identified. Long distance dissemination of Fleck disease is primarily through infected propagative material, which accounts for its worldwide distribution. GFkV is not seed-transmissible but its transmission through dodder has been reported [13]. The general hypothesis about Leafroll viruses, Rugose wood complex and Fleck diseases is that they are not seed transmitted because are phloem restricted [23].

In conclusion, much research has focused on the routes by which the seeds become infected and on the progress of viral infection in reproductive organs during their development up until the seedling stage $[1,7,24]$. Few researchers have addressed the problem of the correlation between breeding techniques and seed transmission of viruses. Thus, the purpose of this study is to monitor virological condition of seedlings obtained by crosses between infected parentals, analyzing the sanitary status of seedlings after the transfer in experimental fields.

\section{Materials and methods}

\subsection{Plant material}

Grapevine breeding material monitored in this study is collected in the experimental conservation vineyards (Lat. 40_57024.5400N, Lon.17_00028.9400E) of the Council for Agricultural Research and Economics (CREA) in Turi (Bari, Italy).

\subsection{Traditional crossbreeding}

In this study, 50 progeny plants from three different traditionally crossbreed seeded and seedless table grape cultivars Almeria x Supernova, Ceresa x Carati, Red Globe $\mathrm{x}$ Regal were investigated.

The crosses were done in spring of 2010 after testing the virological condition of the parents. Emasculation was conducted few days before anthesis, followed by immediate bagging of the inflorescences to avoid contamination with pollen. Artificial pollination was carried out for each cross-combination using the designated male pollen, which had been collected earlier and stored at $4{ }^{\circ} \mathrm{C}$ with relative humidity values of $75 \%$ [25]. After artificial pollination, the emasculated inflorescences were protected by bags until fertilization. Bunches were left on the plant until ripening. At harvesting, the seeds were extracted from the berries and washed first with a $5 \%$ solution of sodium hypochlorite for 10 minutes; next a wash in sterile water was performed with subsequent drying at room temperature. Lastly, the seeds were stratified in a mixture of soil and sand (2:1) for a period of about 6 months, at a temperature of $4{ }^{\circ} \mathrm{C}$ [26].

The seeding was carried out in May 2011 in polystyrene containers using as growth substrate a mixture of soil and sand (2:1). Finally, the seedlings were transplanted and transferred first in greenhouse and in spring of 2012 in the CREA experimental field of Turi [27]. Before the transfer in the field, the seedlings were analyzed by Marker-Assisted Selection approach (MAS): genomic DNA was extracted from a leaf of each plant and alleles of two different microsatellites (ISV2 e ISV4) identified to verify the supposed paternity and to exclude the possibility of auto-pollination [28].

\subsection{RNA extraction}

Total RNA was extracted from $100 \mathrm{mg}$ of phloem scraped from mature canes collected during winter pruning of 2013. Considering the possible uneven distribution of viruses within a given plant, samples from at least two different canes of the same plant were mixed (Decree 13 December of 2011) [29]. All samples were immediately frozen in liquid nitrogen and homogenized $1 \mathrm{~min}$ a $30 \mathrm{~Hz}$ by Qiagen TissueLyser, according to the manufacturer instruction protocol. Total RNA was extracted using the Agilent Plant RNA Isolation Mini Kit. RNA purity and concentration were assessed by determining the spectrophotometric absorbance of the sample at 230, 260 and $280 \mathrm{~nm}$ and the ratio of $\mathrm{A}_{2} 60 / \mathrm{A}_{280}$ and $\mathrm{A}_{260} / \mathrm{A}_{230}$ using a NanoDrop 2000 UV-Vis Spectrophotometer (Thermo Scientific). Total RNA was stored at $-80^{\circ} \mathrm{C}$.

\subsection{Multiplex reverse transcription-polymerase chain reaction}

A multiplex reverse transcription-polymerase chain reaction (mRT-PCR) was performed for simultaneous detection of nine grapevine viruses: Grapevine leafroll-associated virus-1, -2 and -3 (GLRaV-1, -2, -3), Arabis mosaic virus (ArMV), Grapevine fanleaf virus (GFLV), Grapevine virus A (GVA), Grapevine virus B (GVB), Grapevine rupestris stem pitting associated virus (GRSPaV), Grapevine fleck virus $(\mathrm{GFkV})$, in combination with a plant RNA internal control (18S rRNA) used as an indicator of the effectiveness of RNA extraction and RT-PCR [30].

The mRT-PCR products were analyzed by electrophoresis on $2.5 \%$ agarose gels buffered in TAE $1 \mathrm{X}$ 
and visualized on a UV transilluminator after staining with GelRed ${ }^{\mathrm{TM}}$ (Biotium). To ensure the absence of nonspecific amplification, each mRT-PCR run included a no template control, one infected plant sample as positive control and one healthy plant sample as negative control.

\section{Results and discussion}

Before performing the traditional crossbreeding between seeded and seedless table grape cultivars in spring of 2010, we analyzed the virological condition of the parentals chosen for the crosses. As reported in Table 1, viral status of both seed and pollen stock plants was quite compromised.

In particular, for the cross Almeria x Supernova (Table 1a) the two mother plants of Almeria were infected with GLRaV-1, GLRaV-2, GLRaV-3, GFkV and GRSPaV. The Supernova pollen was collected from several plants (42), all infected with different viral combinations of GLRaV-1, GVA, GVB, GFkV and GRSPaV.

Likewise, the plants selected for the cross Ceresa $\mathrm{x}$ Carati (Table 1b) were all infected: the two Ceresa mother plants had GFLV, GVA and GRSPaV; the 43 Carati plants used for the collection of pollen were infected with different combinations of GLRaV-1, GLRaV-3, GFLV, GVA, GVB, GFkV and GRSPaV.

For the cross Red Globe x Regal (Table 1c), viruses were not detected in 19 Red Globe mother plants, two were infected with only GFkV and three with GRSPaV; while the virological condition of Regal pollen stock plants (53) was diverse, as there were both uninfected and infected plants with different combinations of all nine viruses tested.

In order to investigate if seedlings obtained by a cross between infected parentals are also infected, we examined 50 progeny plants for each of the three crosses by collecting phloem material from mature canes of one year old progeny plants, transferred from greenhouse in the CREA experimental field of Turi in spring of 2012. None of the nine viruses associated with the most dangerous grapevine diseases were detected in the 150 progeny plants that were screened (Fig. 1).

The lack of attention paid in the past to the sanitary status of exchange plant material, which has contributed to the spread of infected plants, and the reasons owing to inadequate performance of virus affected cultivars in terms of quality and yeld, make it increasingly urgent the implementation of procedures for the use of healthy material at all stages of the path leading from the breeding to the distribution of a new variety [2].

The main precautions to be observed to obtain fruit crops propagation material free from infectious diseases along all the phases of the process of genetic breeding, as previously reported in literature $[31,32]$, can be summarized in: availability of healthy mother plants (pollen and seeds); control of the sanitary status of progeny, either as seeds (dissected in their components) as well as seedlings in their early vegetative stages (after the emission of the third-fifth leaf); monitoring the sanitary status of selections (visual examinations, biological and molecular assays); propagation of selected material using certified rootstocks, placing and keeping at least two healthy plants for each genotype in insect and nematode free facilities for the whole phase of selection.
Table 1. Virological condition of the parentals chosen for the three crosses $(a, b, c)$ screened for the detection of: Grapevine leafroll-associated virus-1, -2 and -3 (GLRaV-1, -2, -3); Arabis mosaic virus (ArMV); Grapevine fanleaf virus (GFLV); Grapevine virus A (GVA); Grapevine virus B (GVB); Rupestris stem pitting-associated virus (RSPaV); Grapevine fleck virus (GFkV).

a. Almeria x Supernova

\begin{tabular}{|c|c|c|}
\hline AcceName & AcceNumb & Virus \\
\hline Almeria & 2 & $\begin{array}{r}\text { GLRaV-1, GLRaV-2, GLRaV-3, } \\
\text { GFkV, RSPaV }\end{array}$ \\
\hline Supernova & 2 & RSPaV \\
\cline { 2 - 3 } & 5 & GFkV, RSPaV \\
\cline { 2 - 3 } & 9 & GLRaV-1, RSPaV \\
\cline { 2 - 3 } & 1 & GVB, GLRaV-1, RSPaV \\
\cline { 2 - 3 } & 20 & GLRaV-1, GFkV, RSPaV \\
\cline { 2 - 3 } & 1 & $\begin{array}{r}\text { GVB, GLRaV-1, GFkV, } \\
\text { RSPaV }\end{array}$ \\
\cline { 2 - 3 } & 2 & $\begin{array}{r}\text { GVA, GLRaV-1, GFkV, } \\
\text { RSPaV }\end{array}$ \\
\cline { 2 - 3 } & 2 & $\begin{array}{r}\text { GVA, GVB, GLRaV-1, } \\
\text { GFkV, RSPaV }\end{array}$ \\
\hline
\end{tabular}

\begin{tabular}{|c|c|c|}
\hline \multicolumn{3}{|c|}{ b. Ceresa $x$ Carati } \\
\hline AcceName & AcceNumb & Virus \\
\hline Ceresa & 2 & GVA, RSPaV, GFIV \\
\hline \multirow{9}{*}{ Carati } & 1 & GFkV, RSPaV \\
\hline & 29 & GLRaV-1, GLRaV-3, RSPaV \\
\hline & 3 & $\begin{array}{l}\text { GLRaV-1, GLRaV-3, } \\
\text { RSPaV, GFIV }\end{array}$ \\
\hline & 1 & GVA, GLRaV-1, RSPaV, \\
\hline & 3 & $\begin{array}{l}\text { GVB, GLRaV-1, } \\
\text { GLRaV-3, RSPaV }\end{array}$ \\
\hline & 1 & $\begin{array}{l}\text { GLRaV-1, GFkV, } \\
\text { RSPaV, GFIV }\end{array}$ \\
\hline & 3 & $\begin{array}{l}\text { GVA, GVB, GLRaV-1, } \\
\text { GLRaV-3, RSPaV }\end{array}$ \\
\hline & 1 & $\begin{array}{l}\text { GVB, GLRaV-1, GLRaV-3, } \\
\text { RSPaV, GFIV }\end{array}$ \\
\hline & 1 & $\begin{array}{l}\text { GVA, GLRaV-1, GLRaV-3, } \\
\text { RSPaV, GFIV }\end{array}$ \\
\hline
\end{tabular}

\begin{tabular}{|c|c|c|}
\hline \multicolumn{3}{|c|}{ c. Red Globe x Regal } \\
\hline AcceName & AcceNumb & Virus \\
\hline \multirow{3}{*}{ Red Globe } & 19 & NONE \\
\hline & 2 & GFkV \\
\hline & 3 & $\mathrm{RSPaV}$ \\
\hline \multirow{15}{*}{ Regal } & 4 & NONE \\
\hline & 1 & GLRaV-3 \\
\hline & 1 & $\mathrm{RSPaV}$ \\
\hline & 3 & GLRaV-2, GLRaV-3 \\
\hline & 2 & GVB, GLRaV-3 \\
\hline & 7 & GLRaV-3, GFkV \\
\hline & 3 & GLRaV-3, RSPaV \\
\hline & 1 & GLRaV-2, GFkV, RSPaV \\
\hline & 1 & GVB, ArMV, GLRaV-3 \\
\hline & 1 & ArMV, GLRaV-3, RSPaV \\
\hline & 1 & ArMV, GFkV, RSPaV \\
\hline & 16 & GLRaV-3, GFkV, RSPaV \\
\hline & 2 & GLRaV-3, RSPaV, GFIV \\
\hline & 1 & GLRaV-1, GFkV, RSPaV \\
\hline & 1 & $\begin{array}{c}\text { GVA, GVB, } \\
\text { ArMV, GLRaV-3 }\end{array}$ \\
\hline
\end{tabular}


Table 1. Continued.

\begin{tabular}{|c|c|c|}
\hline 3 & $\begin{array}{r}\text { ArMV, GLRaV-3, } \\
\text { GFkV, RSPaV }\end{array}$ \\
\cline { 2 - 3 } & 2 & $\begin{array}{r}\text { GVA, GVB, GLRaV-1, } \\
\text { GLRaV-3, RSPaV }\end{array}$ \\
\cline { 2 - 3 } & 2 & $\begin{array}{r}\text { GVA, GLRaV-1, GLRaV-3, } \\
\text { GFkV, RSPaV }\end{array}$ \\
\cline { 2 - 3 } & 1 & $\begin{array}{r}\text { GVA, GVB, GLRaV-1, } \\
\text { GLRaV-2, GFkV, RSPaV }\end{array}$ \\
\hline
\end{tabular}

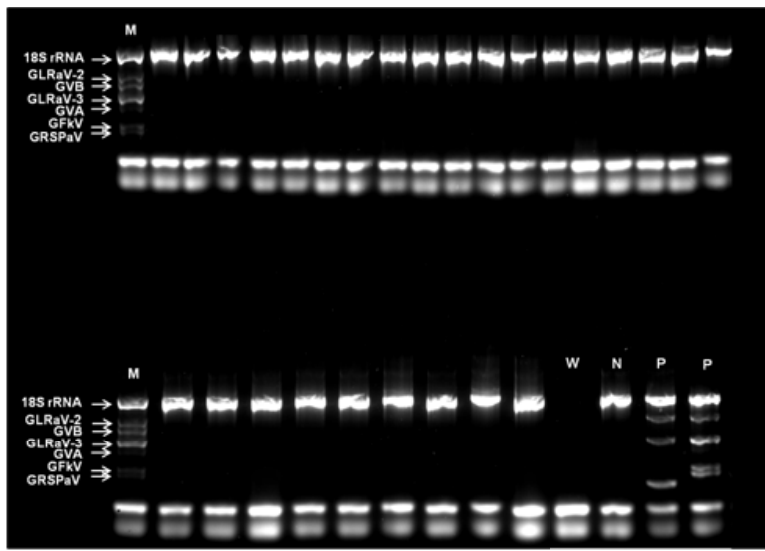

Figure 1. Agarose gel electrophoretic analysis of DNA fragments amplified by multiplex reverse transcription-polymerase chain reaction for the detection of: Grapevine leafroll-associated virus1, -2 and -3 (GLRaV-1, -2, -3), Arabis mosaic virus (ArMV), Grapevine fanleaf virus (GFLV), Grapevine virus A (GVA), Grapevine virus B (GVB), Grapevine rupestris stem pitting associated virus (GRSPaV), Grapevine fleck virus (GFkV). In the first lane (M) there is an our infected sample used as marker for the gel reading; the last four lanes are a no template control $(\mathrm{W})$, the negative control $(\mathrm{N})$ and two positive controls $(\mathrm{P})$ respectively; the other lanes are part of the progeny samples of the Almeria x Supernova cross, in which the viruses analyzed were not detected.

In this study, the virological status of one year old progeny plants after the transfer to experimental fields were analyzed to determine if seedlings obtained by crosses between virus infected parentals are also infected, thus focusing the research on the effective seed transmission of viruses in grapevine breeding material.

Numerous experiments have established that vertical transmission of viruses is a common and important phenomenon affecting a wide range of viruses and host plants. In the majority of cases, it occurs after germination of infected embryos to produce infected seedlings; in only a few examples does the seedling become infected after germination through contamination with virus present in the seed coat [24]. The best example of the processes involved in vertical transmission is the work of Wang and Maule [33] who demonstrated that Pea early browning virus is transmitted by seed after infection of both gametes (indirect way) and that Pea seed borne mosaic virus (PSbMV) is seed-transmitted, although it is not able to infect the gametes (direct way).

Roberts et al. [24] have afterwards showed that PSbMV was able to first infect the testa and then invade the endosperm using the existing symplastic connection.

The virus subsequently reached the embryo through the pore-like structures that are located in the sheath separating the embryo from the suspensor. It has been demonstrated also that seed transmission is related to the ability of the virus to infect flower organs, especially the meristematic reproductive tissue, during early developmental stages [34]. Similarly, Amari et al. [35] have demonstrated that Prunus necrotic ringspot virus (PNRSV) invades apricot reproductive organs, including the pollen mother cell stage, early in development, and after that PNRSV infects all parts of the seed, including embryo, endosperm and testa, shedding light on the vertical transmission of PNRSV from gametes to seedlings [1]. Also the wide natural incidence of the nepovirus Cherry leaf roll virus (CLRV) is believed to have occurred mainly by seed transmission, in fact vertical transmission of CLRV by seed and pollen has been reported to occur naturally by embryo invasion in different works [36-38].

In grapevine, seed transmission has been reported for many nepoviruses, as GBLV, PRMV, BLMoV, TomRSV, GFLV [8-10,12-14], and GRSPaV is considered a potential danger as it has been reported to be present in pollen [15] and seeds [16], but there are no studies in the literature that demonstrate its seed transmission [19,39].

The results presented here show that the nine grapevine viruses analyzed (GLRaV-1, -2, -3, ArMV, GFLV, GVA, GVB, GRSPaV, GFkV) are at low risk for seed transmission during breeding process.

The nepoviruses we analyzed were ArMV e GFLV; while ArMV results in literature not seed-transmitted in grapevines [14] as we reported in our study, Lazar et al. [14] consider GFLV a virus seed-transmitted in grapevines. Their investigations were carried out from 1983 to 1987 in order to verify if grapevine fanleaf virus (GFLV), arabis mosic virus (ArMV), and grapevine chrome mosaic virus (GCMV) were transmitted through the seeds of grapevine. Seeds from infected vines, checked by ELISA, were collected and germinated. The percentage of germination varied from $14 \%$ to $69 \%$. Part of the seeds were crushed and extracts of the whole seed ware tested by ELISA. Among 17 dormant seed groups tested, only one (ArMV) gave negative results. All seedlings grown from seeds of infected vines were symptomless. However, GFLV was detected in 14 of 28 seedlings (50\%) from GFLV-infected vines in the first year, but detection was inconsistent in the following year.

Conversely, seed transmission for GFLV was not documented in our study, contradicting previous reports [12-14]. It's important that in our research we use a more specific molecular technique as the RT-PCR, than the serological test ELISA, and the major number of seedlings we analyzed (over 50) respect previous works, since in the cross Ceresa x Carati (Table 1b) both the two Ceresa mother plants and some Carati plants used for the collection of pollen were affected by GFLV, this has the merit to validate our experimental approach.

Perhaps, GFLV might be inactivated during seedlings development, in fact we analyzed the sanitary status of one year old progeny plants, unlike most previous work.

Regarding GRSPaV, our results confirm its no seed borne property as reported in literature [18,19,39]. In effect, for Almeria x Supernova and Ceresa x Carati crosses all parentals used as seed or pollen stock plants were affected by GRSPaV and even for the cross Red Globe x Regal GRSPaV infected plants were employed. 
Nevertheless, GRSPaV has never been detected in all the progeny plants analyzed.

Also Leafroll viruses, GFkV, GVA and GVB have never been detected in our screening although they are present in different combinations in the parentals of the three crosses, corroborating the general hypothesis that these viruses are not seed transmitted, likely because they are phloem restricted [20-23]. Although it is generally accepted that the Leafroll viruses are phloem limited there is some evidence that GLRaV-2 is not strictly phloem restricted, since Kurth et al. [40] in their work, despite the difficulty to investigate the virus dynamics in the vines due to variability in virus accumulation during the growing season, they surprisingly discovered that in the berries GLRaV-2 is not strictly phloem limited (groups of the large mesocarp cells adjacent to phloem also support viral replication). However, in our work GLRaV-2 wasn't detected in progeny plants.

It's known that most plants prevent virus invasion owing to the high level of protection offered by embryos of their seeds [3] or during metabolic processes associated with germination, the virus is degraded and loses its infectivity, so the presence of virus in a seed, even in the embryo, does not always lead to seedling infection [41]. The inability of the virus to spread through the seed of infected plants has been attributed to several factors. For instance Konaté et al. [42] elucidated that non-seed transmission of a virus is due to its inactivation as the seed matures and begins to lose water following harvest. Nontransmission of a virus could be due to the activity of the vascular tissue and location of the pathogen within the seed and thus prevents infection [7] or owing to the confinement of the same to the vascular tissue instead of the ovule, which is a well-known pathway for virus transmission [43].

In conclusion, our study supports the hypothesis that the grapevine viruses associated with the most relevant diseases considered by the Italian legislation on certification of grapevine propagating material (Leafroll, infectious degeneration, Rugose wood complex and Fleck diseases) are at low risk for seed transmission. Therefore there should be little need to obtain material free from infectious diseases for the breeding process. Once a new vineyard has been established, a grower has limited options to control the damage caused by viruses and therefore the most efficient strategy remains prevention [44]. Our work facilitates the path leading from the breeding to the distribution of a new variety, because makes it no longer necessary to control the virological status of mother plants and progeny, either as seeds as well as seedlings, but it may be sufficient only monitoring the healthy condition of the propagation materials, taking care to use certified rootstocks and soil free from nematodes vectors. The main concern is still to prevent the reinfection after planting, so the selected material must be continuously monitored for the possible occurrence of new symptoms and it is better to use dedicated equipment or clean them carefully to avoid the introduction of infected materials in the gene-banks.

Lastly, our work could lead also a new approach to grapevine sanitation in breeding programs, providing the first evidence of non-seed transmission of grapevine viruses along the genetic breeding process and so suggesting to consider the reproduction as a new procedure of sanitation.

\section{References}

[1] K. Amari, L. Burgos, V. Pallás, M.A. Sánchez-Pina, J. Gen. Virol. 90, 1767-1774 (2009)

[2] D. Bassi, G.P. Martelli, Virus and virus-like diseases of stone fruits, with particular reference to the Mediterranean region, (CIHEAM Options Méditerranéennes: Série B. Etudes et Recherches; n. 45, 2003)

[3] M.T. Salaudeen, Arch Phytopathology Plant Protect 45:20, 2406-2413 (2012)

[4] G.I. Mink, Annu Rev of Phytopathol 31, 375-402 (1993)

[5] R. Hull, Matthews' Plant Virology, 4th edn. (Academic Press, New York, 2002)

[6] D. Wang, A.J. Maule, Plant Cell 6, 777-787 (1994)

[7] F.M. de Assis Filho, J.L. Sherwood, Phytopathology 90, 1233-1238 (2000)

[8] J. K. Uyemoto, E.F. Taschenberg, D.K. Hummer, Plant Dis Rep 61, 949-953 (1977)

[9] D. C. Ramsdell, R. L. Myers, Phytopathology 68, 447-450 (1978)

[10] J.K. Uyemoto, Plant Dis Rep 59, 98-101 (1975)

[11] H.F. Dias, Ann. Appl. Biol. 51, 85-95 (1963)

[12] L. Cory, W.B. Hewitt, Phytopathology 58, 13161320 (1968)

[13] M. Hevin, M.M. Ottenwaelter, J.P. Doazan, M. Rives, Rivista di Patologia Vegetale Serie IV Vol.9, Fasc.3 (Società Italiana di Patologia Vegetale, 1973)

[14] J. Lazar, M. Kölber, J. Lehoczky, Kertgazdasag 22(4), 58-72 (1990)

[15] A. Rowhani, Y.P. Zhang, J. Chin, A. Minafra, D.A. Golino, J. K. Uyemoto, Extended Abstracts of the 13th Meeting ICVG, 82, Adelaide, Australia (2000)

[16] S. Stewart, A.;Nassuth, Plant Dis 85, 617-620 (2001)

[17] B. Meng, R. Credi, N. Petrovic, I. Tomazic, D. Gonsalves, Plant Dis 87, 515-520 (2003)

[18] Y.P. Zhang, J.K. Uyemoto, A. Golino, D.A. Rowhani, Phytopathology 88, 1231-1237 (1998)

[19] M. Morelli, A. Minafra, D. Boscia, J Plant Pathol, 91 4, Supplement (2009)

[20] R. Bovey, W. Gärtel, W.B. Hewitt, G.P. Martelli, A. Vuittenez, Virus and Virus-like Diseases of Grapevine (Payot Editions, Lausanne, 1980)

[21] G.P. Martelli, Graft-transmissible diseases of Grapevines: handbook for detection and diagnosis. (Food and Agriculture Organization of the United Nations, Rome, 45-54, 1993)

[22] M. Laimer, O. Lemaire, E. Herrbach, V. Goldschmidt, A. Minafra, J Plant Pathol 91, 7-23 (2009)

[23] M. Digiaro, G.P. Martelli, V. Savino, Proceedings of the Mediterranean network on grapevine closteroviruses 1992-1997 and the viroses and viruslike diseases of the grapevine a bibliographic report, 1985-1997 (CIHEAM Options Méditerranéennes: Série B. Etudes et Recherches n. 29, 1999)

[24] I.M. Roberts, D. Wang, C.L. Thomas, A.J. Maule, Protoplasma 222, 31-43 (2003)

[25] H.T. Hartmann, D.E. Kester, Propagazione delle piante. (Edagricole, Bologna, Italy, 1990)

[26] J. Janick, J.N. Moore, Fruit breeding Vol II Vine and Small Fruits (John Wiley \& Sons, Inc, 1996) 
[27] L.R. Forleo, R. Perniola, A.R. Caputo, R. Genghi, D. Antonacci, Proc 34th World Congress of Vine and Wine (Porto, Portugal, 2011)

[28] C. Bergamini, L.R. Forleo, C. Sgarra, R. Ragone, V. Durante, M.F. Cardone, D. Antonacci, Proc. 36th. World Congress of Vine and Wine (Bucharest, Romania, 2013)

[29] C.I. Dovas, N.I. Katis, J Virol Methods 109, 217-226 (2003)

[30] G. Gambino, I. Gribaudo, Phytopathology 96, 1223-1229 (2006)

[31] M. Barba, D. Bassi, A. Catara, E. Tribulato, Atti del Convegno Nazionale Certificazione delle produzioni vivaistiche (Locorotondo and Bari, Italy, 1999)

[32] C. Lankes, Acta Horticulturae 538, 681-683 (2000)

[33] D. Wang, A. J. Maule, Plant J 11, 1333-1340 (1997)

[34] C. Vazquez Rovere, M. Del Vas, H.E. Hopp, Curr Opin Biotech 13, 167-172 (2002)

[35] K. Amari, L. Burgos, V. Pallás, M.A. Sánchez-Pina, Phytopathology 97, 892-899 (2007)

[36] F. Dosba, M. Lansac, E. Germain, K. Mazy, M. Rovira, Fruits 45, 171-175 (1990)
[37] M. Bandte, C. Büttner, Pflanzenschutzberichte 59, 1-19 (2001)

[38] A. Rumbou, S. von Bargen, C. Büttner, Eur J Plant Pathol 124, 527-532 (2009)

[39] B. Meng, R. Credi, N. Petrovic, I. Tomazic, D. Gonsalves, Plant Dis 87, 515-520 (2003)

[40] E.G. Kurth, V.V. Peremyslov, A.I. Prokhnevsky, K.D. Kasschau, M. Miller, J.C. Carrington, V. Dolja, J Virol Jun 86(11), 6002-9 (2012)

[41] K. Nakamura, N. Yamagishi, M. Isogai, S. Komori, T. Ito, N. Yoshikawa, J Gen Plant Pathol 77, 48-53 (2011)

[42] G. Konaté, S. Sarra, O. Traoré, Eur J Plant Pathol 107, 361-364 (2001)

[43] M.L. Gleason, R. Providenti, Plant Dis 74(10), 828 (1990)

[44] P. La Notte, P. Venerito, V. Savino, G.P. Martelli, Meeting of COST Actions FA1003 \& FA0807 Phytoplasmas and viruses management in Grapevine Collections for Germplasm Conservation, Mobilization and Evaluation (Sofia, Bulgaria, 2012) 